\title{
Working against and with the State
}

\author{
From Sanctuary to Resettlement
}

\author{
Audrey Macklin
}

\begin{abstract}
A handful of Canadian church congregations provide sanctuary to failed asylum seekers. Many also participate in resettling refugees through a government program called private sponsorship. Both sanctuary and sponsorship arise as specific modes of hospitality in response to practices of exclusion and inclusion under national migration regimes. Sanctuary engages oppositional politics, whereby providers confront and challenge state authority to exclude. Refugee sponsorship embodies a form of collaborative politics, in which sponsorship groups partner with government in settlement and integration. I demonstrate how the state's perspective on asylum versus resettlement structures the relationship between citizen and state and between citizen and refugee. I also reveal that there is more collaboration in sanctuary and resistance in sponsorship than might be supposed.
\end{abstract}

KEYWORDS: hospitality, private sponsorship, refugee, resettlement, sanctuary

The state governs citizens; it rules noncitizens. Both are subject to state power, but not in the same way. For this and many other reasons, citizens encounter refugees (and refugee claimants) on a terrain of inequality. This inequality inevitably seeps into concepts and practices of hospitality and humanitarianism (Derrida 2000). At the same time, the triangulation of state, citizen, and non-citizen can and does produce variegated effects. This article explores the relationship between citizen and state in the context of two local hospitality projects in Canada: one is sanctuary, in which a church congregation shelters failed asylum seekers from deportation; the other is community sponsorship of refugees. Known officially as private sponsorship, this government-created program enables groups of private citizens to participate in resettling refugees to Canada by undertaking to provide a year's financial, social, and practical settlement and integration support.

Both sanctuary and private sponsorship engage a group of citizens in a committed and often intense quotidian relationship with people whom they recognize as refugees. In this article, I focus on church congregations because they are the sanctuary providers in virtually all cases (Rehaag 2009). Similarly, faith-based institutions have been the pillars of private sponsorship in Canada since the program was formally legislated into existence in 1978 (Adelman et al. 1994; Bramadat 2014; Molloy et al. 2017). Sanctuary and sponsorship share a functional similarity, but the launching point for this inquiry is what distinguishes them: sanctuary providers interpose themselves as a shield between those they recognize as refugees and a government bent on refouling (returning) those refugees. Sponsors enlist in a cooperative venture with government 
directed at the enrollment of refugees into citizenship. Sanctuary is about oppositional politics; sponsorship is about collaborative politics.

This article grows out of a larger project that investigates the motives, modality, and effects of private (or community) sponsorship from the perspective of citizen-sponsors. This project asks how participating in a state-sanctioned project of "making refugees into citizens" remakes the citizenship of sponsors. It involved an online survey of almost 600 sponsors, and in-person interviews of 85 sponsors conducted in 2018-19. In the course of interviewing refugee sponsors, researchers met four members of a single sponsorship group that had also provided sanctuary, which prompted curiosity about how these participants compared their experiences as sanctuary providers and as sponsors. The small number of sanctuary provider/ sponsors interviewed counsels against drawing broad theoretical implications from the data. At the same time, it offers an opportunity to contribute to a burgeoning body of literature on citizen-migrant relations organized around themes of hospitality, solidarity, and humanitarianism (Feischmidt et al. 2019; Fleischmann 2019; Merikoski 2020; Rozakou 2016; Vandevoordt 2019).

This article addresses actors who do not transition from collaboration to opposition (or vice versa), but instead toggle between them. The same church congregation that provided sanctuary to refused refugees also participated in private sponsorship of refugees. Canada is a propitious site for inquiry precisely because of the existence of a formal program that enlists private individuals in a state-authorized hospitality project. I argue that the political and legal framework governing border control and refugee admission structures the participants' relationship with the Canadian state. It also inflects their relationship with the refugees they shelter or sponsor, but does not fully determine it. My thesis is that there is more collaboration in sanctuary and more opposition in sponsorship than one might initially suppose, and I use theoretical insights about hospitality to explain this.

The first part of the article situates sanctuary and sponsorship within a statist frame that differentiates asylum from resettlement. More specifically, it explains how states depict asylum as a threat to sovereignty and refugee resettlement as sovereignty's benevolent face. This sets up the distinct political valences of sanctuary and sponsorship. I briefly evaluate the significance of this difference for the exercise of hospitality by church-affiliated providers of sanctuary and sponsorship. Next, I turn to interviews with the church minister and members of a congregation who provided sanctuary to a family of refused asylum seekers for 18 months and subsequently sponsored a Syrian refugee family. Their reflections, supplemented by results from the wider project, enable insight into how both sanctuary providers and sponsors navigate the space between oppositional and collaborative politics.

\section{The View from Sovereignty}

Refugees arrive in the Global North in two ways. Asylum seekers flee their country of origin on their own initiative and ask for refugee protection in the destination country. If their claim is accepted, they receive refugee status. Many are refused. A tiny number of rejected refugee claimants resist expulsion by seeking sanctuary in a church. Randy Lippert (2009) documented 50 sanctuary incidents in Canada between 1983 and 2009; only anecdotal reports exist for the subsequent decade.

A few states also resettle refugees from abroad by pre-screening, choosing, and transporting them from selected countries in the Global South. Refugees resettled to Canada receive income assistance and integration support for the first year. Canada's resettlement program has 
two major streams: Government Assisted Refugees (GARs) receive income support from the government and integration assistance from publicly funded immigrant settlement agencies. Privately Sponsored Refugees (PSRs) are financially and socially supported by a sponsorship group, a collection of private individuals who form a group for the purpose of facilitating the integration of resettled refugees. At a minimum, the sponsorship undertaking commits the group to provide financial, emotional, material, and social support to newly arrived refugees for one year. In reality, refugee sponsorship anticipates the growth of a personal relationship between sponsor and newcomer.

Despite its label, private refugee sponsorship depends significantly on cooperation with the state. It is really more akin to a public-private partnership, where the private actor is not a profit-seeking corporation, but a group of individuals united by the common purpose of assisting refugees on a path to citizenship. In the 40 years since the inception of the private sponsorship model in Canada, over 325,000 refugees have been resettled through this program (IRCC 2019). In recent years, other states have developed privatized models that resemble Canada's to a greater or lesser extent (Fratzke et al. 2019).

Resettled refugees and asylum seekers each occupy different places in the political imaginary of settler societies like Canada, Australia, and the United States. The disparity arises from the way they are framed in relation to state sovereignty. A standard account of state sovereignty makes border control indispensable and definitive: a state is sovereign if and to the extent it exercises unfettered control over the exclusion of noncitizens, the terms and conditions of their admission, their access to membership, and their expulsion. This sovereign prerogative is variously defended by analogies to property and to private associations, by arguments based on national self-determination, and by consequentialist conjecture about the catastrophic consequences of free movement. It is anchored in positive international law and domestic legal doctrine, although its historic pedigree is less sedimented than commonly supposed (Lester 2019; Nafziger 1983). This insistence that sovereignty is measured by the power to choose who enters and remains occludes the fact that sovereignty also subsists in the choice to enter into agreements, treaties, and conventions that constrain the scope of future action. States voluntarily signed and ratified 1951 United Nations Convention Relating to the Status of Refugees, yet dedicate enormous resources to devising ways to minimize or evade its legal obligations.

Across wealthy states, asylum seekers are portrayed as imposing themselves on a receiving state that did not choose them and does not want them. Their unwelcome arrival thus [allegedly] diminishes the sovereign prerogative to exclude noncitizens. This depiction is disingenuous. By signing the Refugee Convention, state parties undertake to admit those who meet the refugee definition, fully anticipating that they may arrive without prior screening or notice and might resort to irregular means of entry. These premises are written into the text of the Refugee Convention. The state retains authority to decide whether an individual asylum seeker meets the refugee definition and thereby warrants protection from refoulement. Refugee claimants make a claim of justice, not charity: they ask the state to do no more (but no less) than fulfill their legal obligations. To the extent that states undertake the role of providing sanctuary from persecution on a national scale, they relieve private citizens and nonstate institutions of moral responsibility to do so.

In theory, states could shed their obligations by renouncing the Convention. Yet they do not. Elena Isayev (2017) notes that from antiquity onward, a nominal embrace of asylum, even (or especially) when it is spurned in practice, was invoked to signify that a polity was "civilized," in contrast to the barbarism of its enemies. In contemporary times, the role of "barbarians" is assigned to countries of the Global South who have not ratified the Refugee Convention and who actually host 85 percent of the world's refugees. Of almost 20 million refugees under the UN High Commissioner for Refugees (UNHCR) mandate in 2018, about 1.2 million refugees 
were referred for resettlement. Of those, less than 5 percent of the number referred for resettlement (fewer than 60,000) or 0.3 percent of the total, were actually resettled to approximately two dozen states (UNHCR 2019). In other words, the odds of resettlement are miniscule.

The UN Convention on Refugees is silent on resettlement of refugees to third countries. This means that no state is under any legal obligation to resettle refugees. The few states that do resettle refugees are free to decide whether, how many, whom, and from where to resettle. Resettlement thus exhibits the face of sovereignty in its most flattering light: states retain control over the admission of strangers but exercise that power to advance humanitarian goals. Analytically, resettlement occupies the space of humanitarianism as opposed to justice to the extent that it is driven by a desire to alleviate suffering and save lives, but is not underwritten by legal obligation or a claim of right. Private sponsorship enlists groups of citizens to supplement the public investment in resettlement with their own money, energy, and social capital. In sum, refugee sponsorship aligns with the sovereign prerogative to admit or exclude at will. Sanctuary resists it.

\section{Sanctuary and Sponsorship as Hospitality}

The positive valence of hospitality emphasizes openness and welcome, potential initiation into deeper and transformative relations, and even evolution in the roles of host and guest. The negative valence focuses on the ineluctable asymmetry of power, conditionality and boundedness embedded in the host-guest dyad.

At least three currents of hospitality scholarship converge at the nexus of church sanctuary and sponsorship. Ann Christin Wagner describes hospitality as a "scale shifter between the local, the national, and the international" (2018: 41). The international refugee regime, national practices of refugee "hosting," and municipal "sanctuary cities" are presented as instantiations of hospitality (cosmopolitan or otherwise), whereby some level of government plays the role of host, and asylum seekers or refugees are always the guests.

But hospitality may also be practiced locally by individuals or groups who play host to newcomers in a practical and literal sense. The shape of this hospitality depends significantly on the presence, nature, and quality of hospitality at the municipal, national, and international levels; how the state facilitates or impedes action by individuals and groups; and how private actors perceive the (in)actions of the state.

This dynamic links to another subfield of scholarly inquiry that addresses the political charge associated with hospitality. William Walters (2004) coined the term "domopolitics" to describe the mobilization of the state as "home" and its territory as the "homeland" to legitimate a repertoire of governance strategies aimed at producing the state as always and "inevitably in need of securing" (Taylor 2020: 513) from external threats. Abigail Taylor (2020) extends domopolitics to an account of "domopolitical hospitality" in which, echoing Derrida, hospitality is a resource of the state that is perpetually at risk and must be strictly rationed in the name of preserving the precondition to hospitality itself. In short, the idiom of home functions to reinscribe sovereign prerogative as definitive of state-led hospitality.

A model of governmental hospitality-hospitality as state apparatus-carries the potential to incite a counter-politics of "everyday" hospitality among citizens and civil society who work in solidarity with asylum seekers and migrants. As Katherina Rozakou (2016: 188) postulates, "mundane human encounters" may contain political potentialities that "challenge state-based definitions, boundaries and lines of power (between citizen and non-citizen, for example)." Dimitrios Theodossopoulos adds that "the de-politicising effect of humanitarianism does not 
preclude the politically empowering potential of humanitarian solidarity" (2016: 181). These everyday practices can spark forms of resistance that Taylor (2020) labels "dissident hospitality," and which Paula Merikoski (2020) dubs "contentious hospitality." The salient point is that the political character of local expressions of hospitality is not fixed or given. It is shaped from above by manifestations of institutional hospitality by the state and laterally by the dynamics of actual relationships.

Lastly, sanctuary and resettlement intertwine secular and faith-based versions of hospitality (see also the special section on Religion and Refugees in this issue). A rich literature explores the overlap and the distinctions between the two, noting that the injunction to "welcome the stranger" finds support in human rights norms and in sacred texts, which practitioners may emphasize differently depending on the audience (Bramadat 2014). This mirrors what Synnove Bendixsen and Trygve Wyller (2019: 2) observe in relation to the Nordic region, namely the entanglement of the religious and the secular in "one and same practice, whether this occurs in a church context or not." For purposes of this article, the focus is on the institutional dimension of church-state relations in the asylum seeker/refugee space.

In Canada, the presence of organized faith-based institutions in the delivery of public services is limited, with a few significant exceptions. Mainstream Christian churches in Canada are active in various domains of social justice, including refugee advocacy, material support for newcomers, and sponsorship. Both the sanctuary framework and the infrastructure of refugee sponsorship owe much to national-level church organizations that advocate for broad policy and legal reform within the parameters of charitable tax status in Canada. However, decisions by churches about sanctuary and sponsorship are made and implemented at the level of the congregation.

Ram Cnaan and D. W. Curtis (2013: 10) make a compelling case for theorizing religious congregations "as a distinct set of locally based nonprofit organizations, albeit with certain distinctive features, such as a commitment to worship and religious education." Quoting Robert Putnam, they describe church congregations as voluntary associations that "provide an important incubator for civic norms, community interests and civic recruitment" (Cnaan and Curtis 2013: 19). Treating the individual congregation as the unit of analysis, and as a distinctive type of civil society actor, offers a useful lens through which to understand the provision of church sanctuary and refugee sponsorship as modes of hospitality infused with secular and spiritual content.

\section{The Politics of Sanctuary}

Beginning in the late 1990s, the Canadian government actively sought to stem the arrival of Roma asylum seekers from the formerly Communist states of Central and Eastern Europe, especially Hungary. With the election of a Conservative government in 2006, Canadian refugee law and policy grew harsher and more restrictive. These shifts were accompanied by a concerted government campaign of vilification against refugees and refugee claimants. Roma asylum seekers were especially stigmatized as "bogus" refugees, frauds, beggars, and criminals.

The acceptance rate for Hungarian Roma refugee claimants dropped precipitously from 2008 onward (Macklin 2013; Rehaag et al. 2016). Among those refused was a couple with a young daughter. Both parents were advocates for Roma rights in Hungary, and sought refugee protection after harassment that culminated in a vicious attack from thugs they believed to be members of the neo-fascist Hungarian Guard. They were represented in Canada by a dishonest lawyer who did not provide them with competent legal advice, did not prepare their case, did not translate or file crucial evidence, and did not appear in person at their hearing. Their ref- 
ugee claim was refused in 2010. They retained new counsel and, on the basis of their previous lawyer's misconduct, sought recourse and a new hearing. They failed and were ordered deported to Hungary. They did not appear for removal. A United Church minister received a call about the family from a refugee advocate and former Catholic nun a few days before Christmas, 2012. She reported the conversation as follows: "[S]he said, you're not going to believe this, ... but his name is Joseph and he has a wife and a child and he needs a place to stay. I was like, 'Okay, that's a little on the nose, but okay."

The minister met with the family's legal counsel, then convened a series of meetings with the church council to review the family's situation, the basis of their original refugee claim, the alleged defects in the refugee determination process, and the implications of offering sanctuary. Congregants understood that immigration officials were not precluded from entering the church and apprehending the family: "It wasn't so much that they were legally inhibited from doing it, but that it would have been such bad PR, that they weren't willing to do it, you know."

They knew that providing sanctuary carried a risk of criminal prosecution, though slight. They weighed the reputational risk in the local community. They considered whether a daycare and dance school that rented space in the church would worry "about . . c criminals living in their building because they were under a deportation order and would be arrested if they left the building, you know?" They wondered about a risk to their charitable tax status. The church congregation was dwindling in number and members were aging, so they doubted their capacity to sustain a family in sanctuary for an extended period. They also recognized that the government of the day actively vilified Roma, and some members rehearsed negative stereotypes of Roma criminality.

In this particular case, the congregation deliberated and voted, using a formula described by the minister as follows:

We asked people to vote with blue or red cards, or yellow, and the idea was, red was "I'm going to stand in the way of this." Yellow was, "I might not be for it, but I'm not going to stand in the way of it." And green was for, "Go for it." And we had people who had deep reservations, but not one single person who said they would stand in the way of it. So we were able to move into that relationship quite peacefully, which is remarkable, as it takes so much resources to help somebody and to do something some would call civil responsibility and some would call civil disobedience, right?

Is sanctuary an act of civil disobedience? The question has renewed salience, given the recent prosecutions for "crimes of solidarity"-actions of individuals who rescue and aid asylum seekers and migrants crossing the Mediterranean and the US-Mexico border (Ouziel 2018; The Guardian 2019; The Independent 2018; Tondo 2019). Technically, sanctuary qualifies as civil disobedience only if providers correctly believe that sheltering a person under a deportation order violates criminal or immigration law, because civil disobedience involves intentional law-breaking. As Sean Rehaag (2009) explains, strong legal arguments are available to contest the assumption that sanctuary violates any positive state law in Canada.

Even if sanctuary does not violate criminal or immigration law, it defies state authority. More than one normative path can lead to this place of resistance. A proponent of open borders might defend sanctuary in terms of freedom of movement, which any [peaceful] noncitizen ought to enjoy. A less ambitious commitment to hospitality, whether secular or spiritual, may justify the subordination of state law to compelling normative claims unrecognized in positive law.

The Canadian Sanctuary Network is a coalition drawn from mainstream churches, ${ }^{1}$ and functions as an advocacy body, a clearinghouse and a source of advice and support on whether 
and how to provide sanctuary (Canadian Sanctuary Network n.d.). The network's "Guidelines for Church Groups and Congregations" (n.d.) provides the following rationale for sanctuary as a "double affirmation of faith": "That human life is sacred and worthy of protection. That there are places and spaces that are beyond the reach of the state."

The claim of jurisdictional autonomy ascribed to houses of worship is unavailable to secular actors and marks out the unique physical and normative space inhabited by religious congregations in comparison to other voluntary associations.

For these reasons, some prefer to describe sanctuary not as civil disobedience, but as a "civil initiative." Under this conception of social action, individuals or groups instantiate and strengthen shared values of the political community by upholding the domestic and international law binding upon the state "even if their governments [do] not" (Cunningham 2012: 172). Thus, one might locate a "civil initiative" somewhere on a continuum between civic engagement and civil disobedience.

The following sanctuary provider's account of his own commitment to sanctuary encompasses many of these elements, beginning with his own personal journey: "I did not, for example, grow up in a [home of] protesting civil disobedience, I grew up in a conservative [home], you follow the law because the law's the law. I have done a lot of growth myself in terms of, 'yeah, but lots of laws are unjust.' There were extenuating circumstances that can cause us to act with mercy."

He relates his growth to his embrace of the Christian duty to welcome the stranger: "We have a duty that I believe is quite clearly spelled out in Scripture to be welcoming to refugees especially those fleeing the state and persecution. ... That it's in our name, we call it the sanctuary where we provide worship. It's meant to be safe space."

Turning to the specific case, however, he identifies the flawed process that culminated in the rejection of the sanctuary family's refugee claim: "[T]hey had fallen victim to a fraudulent lawyer whose tactics were well known, which were being investigated, which were in the process of being investigated, and who, from his position of privilege, had ruthlessly targeted at-risk people.... It's really just a despicable act." This congregant then presented the decision to extend sanctuary as a means of holding the government to account for its refusal to live up to its own legal obligations and the rule of law:

Now the conservative government at the time had a very hardline stance on refugees and particularly on Roma refugees that they were bogus refugees. And the complexities of individual refugee cases aside, we are signatories to the International Declaration of Human Rights and the Refugees. So ... we have a duty to give people fair hearings. They manifestly did not get a fair hearing ... It's a clear injustice. So, the unwillingness of the federal government at that time to intercede and to stand up for the rule of law, which they themselves trumpeted all the time, but they couldn't do because then that presented a political problem for them. So, ... for the sake of a political stance, [they would] throw this family under the bus, who has already been beaten with baseball bats. It's terrible.

These comments testify to the sanctuary providers' posture of resistance toward the government. But the critique of the state underwriting sanctuary is not always or necessarily radical (Czajka 2012) insofar as it implicitly concedes the legitimacy of an asylum apparatus, and the definition of who qualifies for refugee protection. In fact, the escalation in requests for sanctuary in Canada in the mid-1990s forced churches to realize that they could not shelter everyone who asked for sanctuary. This led to the formalization of processes to determine which applicants a church would accept into sanctuary. As Rehaag (2009) recounts, churches eventually found themselves performing an asylum adjudication role parallel to the state. Members of a congregation would review the case, employing the same refugee definition as the state (which 
incorporates in turn the UN Refugee Convention definition), and then make their own determination of whether the asylum seeker qualified as a refugee. In this model, churches who engage in sanctuary remain within-and even replicate-the state's paradigm of border control and asylum, even as they oppose its application in a particular case (Cunningham 2012).

Sanctuary providers often emphasize the procedural defects that led to the denial of refugee status or the unavailability of recourse to rectify the mistake. This focus on process is tactically prudent, but also slightly disingenuous. The slippage lies in the disjuncture between the problem identified and the remedy proposed. And it is in the remedy that sanctuary providers reveal the force of their confrontation with the state. A sovereign state arrogates to itself (and its organs) sole jurisdiction to interpret national law. But churches that provide sanctuary usurp the state's jurisdiction to decide whether a given asylum seeker is a refugee by making their own determination, based on the state's legal norm, but according to the church's own process and judgment. It is in this specific and limited sense that sanctuary relocates sovereignty "by taking it out of the hands of a government-sanctioned official and moving it into moral space of the 'ordinary' citizen" (Cunningham 2012: 172).

Unlike judicial review undertaken by a court, the remedy sanctuary providers seek is not to remit the case for redetermination by the original decision-making body. Sanctuary providers believe they already know the right answer, namely that the person is a refugee. So even when the defect is identified as a faulty process, the desired resolution is not a new process, but a different outcome: reverse the original decision and confer refugee protection. Even if the church applies the same rules as the state, and even if its moral authority to decide entails no enforcement power, it tacitly asserts superior epistemic authority to judge whether someone is a refugee.

Indeed, one can interpret the government's pointed refusal to acknowledge the sanctuary committee as a rebuke for the church's impudence in challenging state authority. The church congregation's minister described her repeated failed attempts to meet with the minister of citizenship and immigration:

The relationship with the immigration minister at the time was a closed door. We were refused access, never took a meeting. I went every single Friday for six weeks to his constituency office in Ajax, and sat there, and he did not meet me once. We took over 200 interfaith members of the Coalition and marched to his doors with Holocaust survivors and said, "You know, we understand the situation in Hungary and you have to let these people in," and they refused to meet with us, so we just dropped our stuff off at the secretary's desk. And whenever there was media around it, the messaging [from government] was clear that we were on the wrong side, you know, that the church should not be making these kinds of decisions and offering sanctuary, that there is a legal process for which the individual should be, you know, going through, and this is not a responsible, viable means to justice, that the [family] were in the wrong and we were in the wrong for pursuing this avenue.

Prior Canadian governments, Liberal and Conservative alike, negotiated with churches to resolve sanctuary cases through "quiet diplomacy." All that changed with the election of a rightwing Conservative majority government in 2011. The new government would give no assurance against breaching sanctuary, and the congregation recognized a real risk that Canadian Border Service Officers would detect and apprehend the family if any family member stepped outside the church. Under these conditions, the church's style of persistent but low-key advocacy shifted to coalition-building and open protest.

An interesting counterpoint to the Conservative government's implacable refusal to engage with the sanctuary providers came from the provincial law society, the legal profession's selfregulating body tasked with gatekeeping entry into the practice of law, setting standards of pro- 
fessional and ethical conduct, and monitoring and disciplining lawyers. The law society came under considerable public pressure and condemnation for its ongoing refusal to address the misconduct of specific refugee lawyers (Rehaag et al. 2016). The law society finally investigated the family's first lawyer who, along with two other lawyers, collectively (and negligently) represented most Hungarian Roma refugee claims in Toronto. Crucially, in order to conduct the discipline hearing, the law society required the testimony of the family in sanctuary but the family would not leave the church for fear of apprehension. After extensive discussions, the law society eventually elected to bring the hearing to the church. Over several days in a makeshift hearing room in the church basement, the disciplinary panel received testimony from the parents about the conduct of their first lawyer. The performance of a legal proceeding within the sanctuary space was a moment of legal pluralism, a recognition that law (in the broadest sense) is negotiated, created, and manifested in diverse spaces by actors within and outside the state's designation (Macdonald 1998). The law society ruled that the first lawyer was indeed negligent, but the Conservative government remained intransigent and refused to grant the family even a temporary permit to remain while they pursued the other legal recourses available to them.

The family spent almost three years avoiding deportation and more than 18 months in church sanctuary. Their young daughter eventually reached school age but could not access education because her parents feared that immigration enforcement might find and apprehend her at school. And so the family surrendered and submitted to deportation to Hungary in December 2014. They maintained contact with the sanctuary committee after their removal. A year after the family's deportation, a Liberal government was elected, and the new minister of citizenship and immigration facilitated the family's return to Canada as permanent residents in 2016.

\section{Politicizing Sponsorship}

The current private sponsorship program creates a unique opportunity structure for Canadians to channel their motivation to support refugees into a more direct and engaged medium than a charitable donation. But versions of community sponsorship have long existed in Canada, largely operated by churches and diasporic organizations, even before it was formalized in the 1976 Immigration Act. One indicator of these organizations' trusted relationship with government is the existence of framework agreements between government and more than 70 faithbased and secular institutions (Sponsorship Agreement Holders, or SAHs) that ensure stability and continuity in sponsorship on a relatively large scale. The same church that provided sanctuary to the Roma family had sponsored Indochinese refugees 40 years earlier. Only a handful of the original sponsors remained but, in the words of the minister, they formed a "small contingent that held the DNA of this church as a social justice church," and they supported the sanctuary undertaking. The experience of sanctuary was exhausting but also sparked growth in new, younger membership, who encouraged the congregation to contemplate sponsorship. A congregant describes how he came to assume a leadership role in sponsoring a Syrian family:

There were a number of people in the church who felt, after [the family] had been deported, we felt, "what do we do with this experience now?" And at the time, we didn't know if the family was going to be able to come back ... I think we were all feeling kind of perplexed about what that all meant, and why that experience happened ... So I think the sanctuary episode really put ... supporting refugees, supporting asylum seekers, in the minds of a number of people in the church community. And so then of course when the Syrian refugee crisis began to really explode, I stepped forward and said to [the minister], could we get together and sponsor a family. 
Pivoting from sanctuary to sponsorship involves a switch from an oppositional relationship with the state to a collaborative one in which government and sponsors partner in the joint enterprise of resettling and integrating refugees.

The historical path to this institutional relationship matters to its character. In the Canadian case, the incorporation of community sponsorship into law in 1978 enrolled churches and nonfaith-based civil society actors into an ongoing partnership with government. The community sponsorship model gave them more autonomy vis-à-vis government than faith-based national voluntary agencies in the United States, but still embedded them in a relationship with the state that they could not afford to jeopardize (Cameron 2018). This pragmatism came under strain, however, when the same Conservative government that held power when the Roma family was in sanctuary also took aim at private refugee sponsorship, revising policies and adding restrictions to re-assert greater control over the program and to reduce resettlement numbers (Labman 2016). In effect, the Conservative government took the view that permitting nonstate, civil society actors to select refugees amounted to an internal erosion of sovereignty. The delegation of responsibility and the reliance on private philanthropy that right-wing governments generally extol as virtues of privatization were recast as a diminution of state authority.

Some faith-based institutions feared that the Conservative government was fundamentally hostile to refugees and that the future of resettlement was at risk. This tilted some organizations in a more adversarial direction, as this report revealed: "Some SAHs believe the most realistic way to improve the [private sponsorship] program is by keeping the doors open with those in power, while others feel that the only way to move forward is by changing those in power" (Citizens for Public Justice 2014: 12).

Following the election of a new Liberal government in the fall 2015, relations between government and sponsorship institutions reverted to a more cooperative tone, especially given the intense attention to the Syrian situation. But friction remained, and the nature of the conflicts are revealing, especially when viewed in a comparative light. German scholar Larissa Fleischmann (2019) documents the interaction between state authorities and the burgeoning numbers of Germans who volunteered to assist asylum seekers around the 2015 "German summer of migration." Despite their initial apolitical orientation, many volunteers came to resent top-down state interventions that attempted to direct their activities (2019: 69). Some volunteers balked at the expectation that they would counsel asylum seekers to submit to "voluntary return" or otherwise acquiesce uncritically in removals of the people they had volunteered to assist and support (2019: 70).

This politicizing catalyst rarely arises in Canadian refugee resettlement because, by definition, all resettled refugees have been pre-authorized by the state. But although sponsorship does not challenge the state's authority to admit, individuals and sponsorship groups may challenge how the state exercises its authority. An anecdote from early in the Liberal government's new administration serves to illustrate how this can arise. In March 2016, more than 300 people gathered in a Toronto church hall for an evening meeting with a federal Member of Parliament. The audience for the meeting were among the thousands of Canadians engaged in private sponsorship of refugees. They had joined groups, raised money, completed complicated forms, submitted applications, and been assigned a Syrian refugee family in need of resettlement from Turkey, Lebanon, or Jordan. Some had even rented apartments, now lying vacant. They assailed the government for delays in processing and transporting Syrian refugees to Canada. Sponsors complained that the government was not doing its job and so impeding sponsors from doing theirs.

The political subject position of these refugee sponsors emerged not in spite of the privatization of resettlement, but because of it (Flynn and Cannon 2009; Flynn and Flynn 2018). Sponsors' direct and personal commitment to resettlement provides them with a private interest 
and political voice in the resettlement regime. Many first-time sponsors were drawn from mainstream, middle-class, educated echelons of society and framed their actions in humanitarian rather than activist terms. Yet, they also felt comfortable making political demands on government to expedite the arrival of refugees, precisely because, as private citizens contributing their own time and money, they were doing the "heavy lifting." Somewhat ironically, their role as private "partners" in resettlement gave sponsors a personal stake and a motivation to mobilize politically on behalf of refugees to an extent that is otherwise difficult to achieve in relation to voluntary civic undertakings. This episode illustrates that even within the collaborative politics of resettlement, the state's assertion of sovereign authority to decide who, how, and how many to resettle did not go uncontested.

\section{Analysis}

How do theories about hospitality illuminate the dynamics of oppositional and collaborative politics in congregational practices of sanctuary and resettlement? Attending to the scalar dimension of hospitality, in tandem with the view from sovereignty, situates the refugee regime as a rights-based model of hospitality. In practice, all wealthy, industrialized states defect from this regime to a greater or lesser degree. Highly restrictive refugee determination systems that deny refugee status to most applicants is one means for reducing state obligations. Church sanctuary resists but does not-perhaps cannot—reject entirely the apparatus of refugee determination at the state level.

Sanctuary is a genuinely scarce resource and places extraordinary demands on the material, spiritual, and emotional resources of congregations. How does one decide whom to admit into sanctuary? Sanctuary providers do not apply a humanitarian lens that assesses candidates "through their physical and biological needs, rather than their lived experiences as social and political subjects" (Vandevoordt 2019: 251). Congregations cannot escape regarding asylum seekers as subjects constituted through the international legal category of refugee that the state has incorporated and applied in its domestic refugee determination system. That refugee definition is narrow. In making the critical decision, congregations typically provide their own interpretation of what international and domestic law require in the circumstances. In so doing, congregations re-enact at the local scale what Bendixsen and Wyller (2019) describe as "the central paradox and the tragedy of hospitality: The law that authorizes hospitality simultaneously authorizes its denial. But without this law, hospitality as a right cannot exist, and with the law, hospitality is limited" (2019: 7).

In contrast to asylum, resettlement is a model of humanitarian hospitality driven by benevolence and relief from suffering. The state has no obligation to resettle nor to create the legal infrastructure enabling community sponsorship; no individual or congregation has a duty to undertake private sponsorship. In this sense, state policy and congregational practice operate harmoniously at different scales within a humanitarian framework.

Attending to the scalar dimension of hospitality also invites attention to how state-level policy and practice configure the political content of grassroots hospitality. For example, sanctuary providers accept the legitimacy of the refugee definition adopted into Canadian law but challenge the integrity of the state's refugee determination apparatus and assert jurisdiction to exercise judgment at the level of the congregation. Sanctuary is a civil initiative that does not contest the standard of entitlement to refugee protection, but it does advance a pluralist conception of epistemic and interpretive authority. In the Canadian context, the challenges of operating within the requirements and limitations of the community sponsorship program generates advocacy 
around programmatic deficiencies, such as delays in processing and transporting refugees to Canada, the imposition of annual quotas on the number and source countries for resettlement, and management of expectations between sponsors and government agencies over the course of the sponsorship period.

State practice also influences the practice of hospitality by configuring power relations between sanctuary provider/sponsor and refugee. As noted earlier, asymmetrical power relations are baked into the guest-host binary of hospitality. All interview subjects grasped this fact without any prompting. They reflected on the critical importance of respecting the autonomy of refugees and facilitating their independence in challenging circumstances. Indeed, as Christine Straehle (2020: 532) argues, standing in solidarity with refugees means addressing their "social deprivation and denial of community membership," and how these impede the realization of human autonomy and agency. The fact that sanctuary providers put themselves "on the line" against the state for those in sanctuary marks their relationship as one of deep solidarity. Yet, as one participant reflected, this solidaristic connection did not diminish the power imbalance and may even have exacerbated it. He remarked that constituting the church as a refuge from external danger also demarcated it as a quasi-carceral space that the refugees could not leave. He found it infantilizing, unnatural, and extremely stressful to engage in "restricting someone else's freedoms that way." In effect, he captured the paradoxical position of sanctuary "hosts" up against punitive government policy: in order to advance the solidaristic goal of creating the conditions for agency and autonomy of refugees, sanctuary providers become implicated in restricting the liberty they seek to secure.

The congregants who participated in both sanctuary and sponsorship moved fluently between secular and spiritual discourses of hospitality. A commitment to "faithful hospitality" played a critical role in motivating the decision, but pragmatic considerations about the capacity of the congregation to assume the financial, spiritual, logistical, and reputational burdens also informed deliberations, especially with respect to sanctuary. This suggests the utility and explanatory power of taking the congregation seriously as a particular type of voluntary association. The attention paid to process in the original decision about sanctuary or sponsorship also highlights the character of a religious congregation as an institution with a history, governance structure and normative foundation that transcends provision of support to refugees and asylum seekers. This distinguishes it from civil society organizations dedicated specifically to migration and/or human rights, and from sponsorship groups that form for the sole purpose of sponsorship. This infrastructure can be an asset for congregations because it provides members with a reservoir of collective experience, commitment to governance, and institutional stability required to sustain long-term undertakings in the name of the congregation.

While support for migrants does not constitute the identity of a religious congregation, the raison dêtre of most faith-based organizations includes a humanitarian vocation to helping others in need. Among some congregations, this extends to the promotion of social justice on a broader scale. One consequence is that "religious congregations view their service as inseparable from their self-understanding as 'communities of care.' As they serve others, they also serve themselves, becoming stronger as a community of believers" (Cnaan and Curtis 2013: 20). The idea that hospitality benefits the host as much as the guest (to the point of blurring the distinction between the identity of host and guest) is a familiar proposition with respect to individuals. But it also resonates at the congregational level. Providing sanctuary for 18 months was extremely challenging and often discouraging, but it also united the congregation around an undertaking that was spiritually and practically meaningful. In the darkest moments, when the congregation had to confront their failure to prevent the family's removal, the minister could 
remind the congregation that they had collectively remained faithful to their spiritual calling and to the family throughout. The minister's dynamism and ability to traverse the secular and spiritual dimensions of hospitality (and social justice more generally) played a role in reviving the congregation within the community as a voluntary association serving the spiritual and secular aspirations of its congregants.

\title{
Conclusion
}

Those with the dual experience of providing sanctuary and sponsoring refugees must navigate through and between both oppositional and collaborative politics of sanctuary. The effects ramify various encounters and experiences of daily life. One congregant who was part of the sanctuary support team (and whose child was one of the few playmates that the child in sanctuary had) explained how the contrast in political positions was "probably the biggest difference between the two experiences," and then continued:

\begin{abstract}
There was a feeling, too, in the case of the sanctuary, that you had to be careful who you talk to about it. It was actually not something that was meant to be shared with anybody, so unless it was somebody that you already knew, there's a certain guardedness about it, which was very different, of course, from the experience with the Syrian crisis, where there wasn't any feeling that you had to hide. I mean everybody was sponsoring Syrian families, and everybody was in support of the idea ... I never felt at any time [sponsorship] was something that might be politically dangerous to talk about, whereas the sanctuary experience was something that is, you know, for all sorts of reasons, for their own protection, for just not getting yourself into an uncomfortable argument, that wasn't something that you could really discuss.
\end{abstract}

Those who provide sanctuary to asylum seekers and also sponsor refugees are compelled to reflect critically on the legal categories of asylum seeker and resettled refugee. By standing in solidarity with the refused asylum seeker against the state, and supporting the resettled refugee along with the state, their exercises of hospitality exhibit flexibility toward the exercise of public power and authority. Where the state does not comply with its own legal obligations at the national scale, sanctuary providers resist via local hospitality. Where the state constructs a bridge between global injustice and local hospitality, sponsors seize the opportunity to participate. In so doing, they sustain a moral commitment to a conception of justice that does not require them to repudiate the legal categories; the refugee definition still matters. At the same time, they insist on both the responsibility and authority to participate in constituting membership in the political community. This enables them to travel lightly along the spectrum between oppositional and collaborative politics. A participant in sanctuary and sponsorship summed it up this way: "Sometimes, you know, what you believe to be right may conflict with the government's position. In sponsorship, that element is gone in the sense that this is a government-sanctioned program, so that I'm still able to do the kind of support to a family that I did in [the sanctuary] case, but to do it in a different way, through a church sponsorship program. But it is all motivated by faith and a belief in justice."

From the perspective of the sovereign, sanctuary providers defy the state and sponsors cooperate with the state. The situation is more fluid for those who do both; there is more collaboration in sanctuary and more opposition in sponsorship than one might suppose. But this is not a dilemma for them, because they embrace a politics of hospitality that is framed by a faithful understanding of who refugees are and what justice and humanitarianism require within the social and legal order they inhabit. The rest is tactics. 


\section{ACKNOWLEDGEMENTS}

This article comes from a larger collaboration with Audrey Macklin, Kathryn Barber, Luin Goldring, Jennifer Hyndman, Anna Korteweg, Shauna Labman and Jona Zyfi. The research was initiated through a Canadian SSHRC/IRCC Rapid Response Grant with Audrey Macklin as Principal Investigator and expanded through the support of her Pierre Elliott Trudeau Foundation Project "Re-Settler Society: Making and Remaking Citizenship through Private Refugee Sponsorship." I thank Luin Goldring and Amar Khoday for their generosity in reading and commenting constructively on earlier drafts, two anonymous reviewers who provided helpful criticism, and Laura Madakoro for editing beyond the call of duty. I am also grateful to the conveners and participants in the Stakes of Sanctuary workshop, 7 March 2019, McGill University, for their insights and feedback.

AUDREY MACKLIN is a Professor in the Faculty of Law and Centre for Criminology and Sociolegal Studies, University of Toronto, Toronto, Canada. She teaches, researches and writes in migration and citizenship law, administrative law, and business and human rights. She is a Trudeau Foundation Fellow and a Fellow of the Canadian Institute for Advanced Research (CIFAR). E-mail: audrey.macklin@utoronto.ca.

\section{REFERENCES}

Adelman, Howard, Alan Borowski, Meyer Burstein, and Lois Foster, eds. 1994. Immigration and Refugee Policy: Australia and Canada Compared. Toronto: University of Toronto Press.

Bendixsen, Synnove, and Trygve Wyller. 2019. "Introduction: Contexualized Hospitalities: Migrants and the Nordic Between the Religious/Secular Binary." In Contested Hospitalities in a Time of Migration: Religious and Secular Counterspaces in the Nordic Region, ed. Synnove Bendixsen and Trygve Wyller, 1-16. New York: Routledge.

Bramadat, Paul. 2014. "Don’t Ask, Don’t Tell: Refugee Settlement and Religion in British Columbia." Journal of the American Academy of Religion 82 (4): 907-937.

Cameron, Geoffrey. 2020. "Reluctant Partnership: A Political History of Private Sponsorship in Canada (1947-80)." In Strangers to Neighbours, ed. Shauna Labman and Geoffrey Cameron, 19-41. Montreal: McGill-Queens University Press.

Canadian Sanctuary Network. "Guidelines for Church Groups and Congregations Considering Sanctuary." Sanctuarycanada.ca. n.d. https://sanctnet.apps01.yorku.ca/?page_id=71 (accessed 11 February 2021).

Citizens for Public Justice. 2014. "Private Sponsorship and Public Policy: Political Barriers to ChurchConnected Refugee Resettlement in Canada." https://cpj.ca/private-sponsorship-and-public-policy/ (accessed 29 January 2021).

Cnaan, Ram A., and D. W. Curtis. 2013. "Religious Congregations as Voluntary Associations: An Overview." Nonprofit \& Voluntary Sector Quarterly 42 (1): 7-33.

Cunningham, Hilary. 2012. "The Emergence of the Ontario Sanctuary Coalition: From Humanitarian and Compassionate Review to Civil Initiative." In Lippert and Rehaag, Sanctuary Practices in International Perspective, 162-174.

Czajka, Agnes. 2012. "The Potential of Sanctuary: Acts of Sanctuary through the Lens of the Camp." In Lippert and Rehaag, Sanctuary Practices in International Perspective, 43-56.

Derrida, Jacques, with Anne Dufourmantelle. 2000. Of Hospitality. Stanford, CA: Stanford University Press. 
Feischmidt, Margit, Ludger Pries, and Celine Cantat, eds. 2019. Refugee Protection and Civil Society in Europe. Basingstoke: Palgrave Macmillan.

Fleischmann, Larissa. 2019. "Making Volunteering with Refugees Governable: The Contested Role of 'Civil Society' in the German Welcome Culture." Social Inclusion 7 (2): 64-73.

Flynn, Michael, and Cecilia Cannon. 2009. "The Privatization of Immigration Detention: A Global View." Global Detention Project. https://www.globaldetentionproject.org/wp-content/uploads/ 2016/06/GDP_PrivatizationPaper_Final5.pdf (accessed 29 January 2021).

Flynn, Michael, and Matthew Flynn. 2018. "Uneven Business: Privatisation of Immigration Detention in Europe." Global Detention Project, 8 February. https://www.globaldetentionproject.org/ uneven-business-privatisation-of-immigration-detention-in-europe.

Fratzke, Susan, Leina Kainz, Hanne Beirans, Emma Dorst and Jessica Bolter, "Refugee Sponsorship Programmes: A Global State of Play and Opportunities for Investment." MPI Europe Policy Brief. December 2019.

The Guardian. 2019. "Activist Arrested for Giving Migrants Food and Shelter Faces Retrial." 2 July. https://www.theguardian.com/us-news/2019/jul/02/activist-helped-migrants-retrial-scott-warren.

Immigration, Refugees and Citizenship Canada (IRCC). 2019. "By the Numbers: 40 Years of Private Refugee Sponsorship in Canada." https://www.canada.ca/en/immigration-refugees-citizenship/ news/2019/04/by-the-numbers--40-years-of-canadas-private-sponsorship-of-refugees-program .html (accessed 29 January 2021).

Isayev, Elena. 2017. "Between Hospitality and Asylum: Historical Perspective on Displaced Agency." International Review of the Red Cross 99 (904): 75-98.

Labman, Shauna. 2016. "Private Sponsorship: Complementary or Conflicting Interests." Refuge 32 (2): 67-80.

Lester, Eve. 2019. Making Migration Law: The Foreigner, Sovereignty and the Case of Australia. Cambridge: Cambridge University Press.

Lippert, Randy. 2009. "Whither Sanctuary." Refuge 26 (1): 57-67.

Lippert, Randy, and Sean Rehaag, eds. 2012. Sanctuary Practices in International Perspective: Migration, Citizenship and Social Movements. New York: Routledge.

Macdonald, Roderick. 1998. "Metaphors of Multiplicity: Civil Society, Regimes and Legal Pluralism." Arizona Journal of International and Comparative Law 15: 69-91.

Macklin, Audrey. 2013. "A Safe Country to Emulate?” In The Global Reach of European Refugee Law, ed. Helene Lambert, Jane McAdam, and Maryellen Fullerton, 99-131. Cambridge: Cambridge University Press.

Merikoski, Paula. 2020. “At Least They Are Welcome in My Home!' Contentious Hospitality in Home Accommodation of Asylum Seekers in Finland." Citizenship Studies 25 (1): 95-105. https://doi.org/ 10.1080/13621025.2020.1769558.

Molloy, Michael, Peter Duschinsky, Kurt Jensen, and Robert Shalka. 2017. Running on Empty: Canada and the Indochinese Refugees, 1975-1980. Kingston: McGill-Queen's University Press.

Nafziger, James. 1983. "The General Admission of Aliens under International Law." American Journal of International Law 77 (4): 804-847.

Ouziel, Pablo. 2018. "Non-Violent Communion versus Medieval Ships of Fools: Engaged Citizenry's Alternatives to Europe's War on Refugees." In Legal Violence and the Limits of the Law, ed. Joshua Nichols and Amy Swiffen, 164-188. New York: Routledge.

Rehaag, Sean. 2009. "Bordering on Legality: Canadian Church Sanctuary and the Rule of Law." Refuge 26 (1): 43-56.

Rehaag, Sean, Julianna Beaudoin, and Jennifer Danch. 2016. "No Refuge: Hungarian Romani Refugee Claimants in Canada." Osgoode Hall Law Journal 52 (3): 705-774.

Rozakou, Katherina. 2016. "Socialities of Solidarity: Revisiting the Gift Taboo in Times of Crisis." Social Anthropology 24 (2): 185-199.

Straehle, Christine. 2020. "Associative Solidarity, Relational Goods, and Autonomy for Refugees: What Does it Mean to Stand in Solidarity with Refugees?" Journal of Social Philosophy 51 (4): 526-542. https://doi.org/10.1111/josp.12339. 
Taylor, Abigail. 2020. "Domopolitics, Citizenship and Dissent: An Analysis of 'Crimes of Solidarity' and Hospitality in Contemporary France." International Journal Politics, Culture and Society 33: 495-512.

Theodossopoulos, Dimitrios. 2016. "Philanthropy or Solidarity? Ethical Dilemmas about Humanitarianism in Crisis-Afflicted Greece." Social Anthropology 24 (2): 167-184.

Tondo, Lorenzo. 2019. “O Captain, My Captain: Sailors Who Risk Jail to Save Migrants' Lives." The Guardian, 5 July. https://www.theguardian.com/world/2019/jul/05/o-captain-my-captain-sailorswho-risk-jail-to-save-migrants-lives.

UN High Commissioner for Refugees (UNHCR). 2019. "Less than 5 Percent of Global Resettlement Needs Met Last Year," 22 February. https://www.unhcr.org/5c6bc9704.

Vandevoordt, Robin. 2019. "Subversive Humanitarianism: Rethinking Refugee Solidarity through GrassRoots Initiatives." Refuge Survey Quarterly 24 (2): 245-265.

Wagner, Ann-Christin. 2018. "Giving Aid Inside the Home: Humanitarian House Visits, Performative Refugeehood, and Social Control of Syrians in Jordan." Migration and Society 1: 36-50.

Walters, William. 2004. "Secure Borders, Safe Haven, Domopolitics." Citizenship Studies 8 (3): 237-260. 